Journal of Southeast Asian

2013

\title{
Selected Poems: Twin; Prolonging/Palaung-ing it
}

Somphet Phonvongsa

somphet1987@gmail.com

Follow this and additional works at: https://docs.lib.purdue.edu/jsaaea

\section{Recommended Citation}

Phonvongsa, Somphet (2013) "Selected Poems: Twin; Prolonging/Palaung-ing it," Journal of Southeast Asian American Education and Advancement. Vol. 8 : Iss. 1, Article 17.

DOI: $10.7771 / 2153-8999.1072$

Available at: https://docs.lib.purdue.edu/jsaaea/vol8/iss1/17

This document has been made available through Purdue e-Pubs, a service of the Purdue University Libraries. Please contact epubs@purdue.edu for additional information.

This is an Open Access journal. This means that it uses a funding model that does not charge readers or their institutions for access. Readers may freely read, download, copy, distribute, print, search, or link to the full texts of articles. This journal is covered under the CC BY-NC-ND license. 


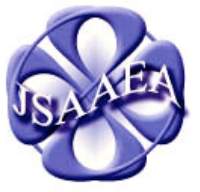

Volume 8 (2013)

\section{Journal of Southeast Asian American Education \& Advancement}

WWw.JSAAEA.org
A peer-reviewed scholarly journal published by the National Association for the Education \& Advancement of Cambodian, Laotian, and Vietnamese Americans (NAFEA)

\section{Selected Poems}

\section{by \\ Somphet Phonvongsa}

\section{Twin}

(Dedicated to Somphet Pheauboonma)

She is cool not nga:r (cold)

Because her heart is warm not si jeun'nga:r (green)

Moi (1), ba:r (2) like twin

She is my kin

Fly like a sim (bird) or is it a kreuang bin (airplane)?

I like how she dten (dance), how she din (stand)

Natural like the trees, natural like the wind

In her element, her poetry is relevant

Spiritual, she is heaven sent

One with the cosmos, she la:r (spread) her soul

Healthy in spirit and mind

I'm glad her 32's stayed to keep her fine

My Sonoma, she is the heart of wine (country)

Flow, flow she keeps me bai:n (drunk)

But I'm going to check myself, keep myself in line

I just want to tell her she is cool like the Hindu Kush

Fly like the effects of northern lights and kush

The peace, the light, the opposite of Bush

And because she had time to come to the Bush

I will push, push my tush all the way to the "Rose"

And finally show off my flows

\footnotetext{
(c)

SOMERIGHISRESERED Readers are free to copy, display, and distribute this article, as long as the work is attributed to the author(s) and the Journal of Southeast Asian American Education \& Advancement, it is distributed for noncommercial purposes only, and no alteration or transformation is made in the work. More details of this Creative Commons license are available at http://creativecommons.org/licenses/by-nc-nd/3.0/. All other uses must be approved by the author(s) or JSAAEA.
} 


\section{Prolonging/Palaung-ing it}

(Dedicated to Somphet Pheauboonma)

She says she knows how we linguist be

So I tell her that I like to be free, like to free

My soul with that thing that is heat (dance)

But I dance with stars so they can guide my 32's and my heart

Because a part of me is feeling that if I ever went home

They would've told me that I don't belong here

But that's me feeling paranoid, a cultural void

I'm still looking for that poise, that sense of peace

They call me dek noi so I guess I'm making that dek noise

I want to make a difference in my society

But my poetry is dead like Latin, living only on these sheets

Do I really need beats to say "Can I live?"

I want to be like her, feel a sense of belonging

My other half who is also half Khmu

Is more Lua but she's down with the goong (village)

So she's unlike me, I need to pursue the bpasoom (the meeting)

The bpooh soong (my village)

Because the more and more I drift off, I become Thai or Loom

And that's problematic for me because half my life I've been rocking fruit of the "loom"

It's not to say no hope, all doom

If I consume a bit of their culture

But it's more of a wonder if I can uplift mine's

And balance it all without going under

I don't want to keep sounding overzealous but I just want to prolong it

Like her bond with Palaungic

Because this is what I belong with

Where I derived from, what I drive, strive for

Probably die for but I won't kill like the Sudanese in Darfur

This is where dancing with the astrology got me

And what an odyssey

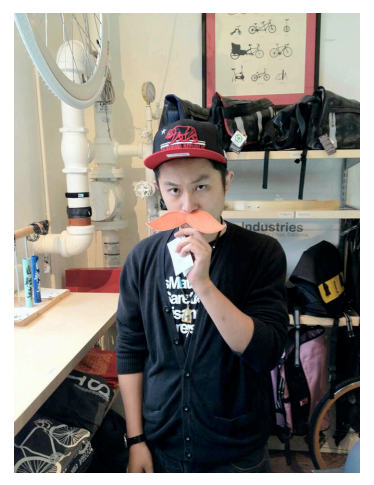

\section{About the Author}

Somphet Phonvongsa was born on August 7th of 1987 in San Pablo, California to Say and Pinhkeo Phonvongsa. He is a first generation $\mathrm{Khmu}$ /Tai Lue American, a child of five, a son of refugees, a blogger, a poet and a blue-collar worker. His dreams are to recapture the spirits of the old world and to showcase it to the new world. 


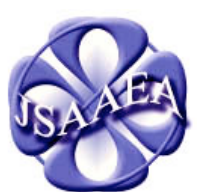

Volume 8 (2013)

\section{Journal of Southeast Asian American Education \& Advancement}

\author{
WwW.JSAAEA.org
}

\section{Editor}

Dr. Wayne E. Wright

University of Texas, San Antonio

\author{
Associate Editors \\ Dr. Chhany Sak-Humphry \\ University of Hawaii at Manoa
}

Dr. Phitsamay Sychitkokhong Uy

University of Massachusetts, Lowell

\section{Book Review Editor}

Dr. Vichet Chhuon

University of Minnesota

\section{Creative Works Editor \\ Bryan Thao Worra \\ Lao Assistance Center}

Special Advisor

Gregory Green

Curator, Echols Collection on Southeast Asia, Cornell University Library

Journal Manager

Sovicheth Boun

University of Texas, San Antonio
A peer-reviewed

scholarly journal published by the

National Association

for the Education \&

Advancement of

Cambodian, Laotian,

and Vietnamese

Americans (NAFEA)

Comments and questions for the editorial staff may be directed to jsaaea@1ists.sis.utsa.edu

\section{Editorial Review Board}

\author{
Dr. Steve Arounsack \\ California State University, Stanislaus \\ Dr. Phala Chea \\ Lowell Public Schools \\ Dr. Loan Dao \\ University of Massachusetts, Boston \\ Dr. Changming Duan \\ University of Missouri, Kansas City \\ Dr. Jeremy Hein \\ University of Wisconsin - Eau Claire \\ Dr. Samlong Inthaly \\ Minneapolis Public Schools \\ Dr. Kevin K. Kumashiro \\ University of Illinois, Chicago
}

Dr. Carl L. Bankston III

Tulane University

Dr. George Chigas

University of Massachusetts, Lowell

Dr. Hien Duc Do

San Jose State University

Dr. Sophal Ear

U.S. Naval Postgraduate School

Dr. Nancy H. Hornberger

University of Pennsylvania

Dr. Peter Nien-Chu Kiang

University of Massachusetts, Boston

Dr. Ha Lam

Arizona State University 

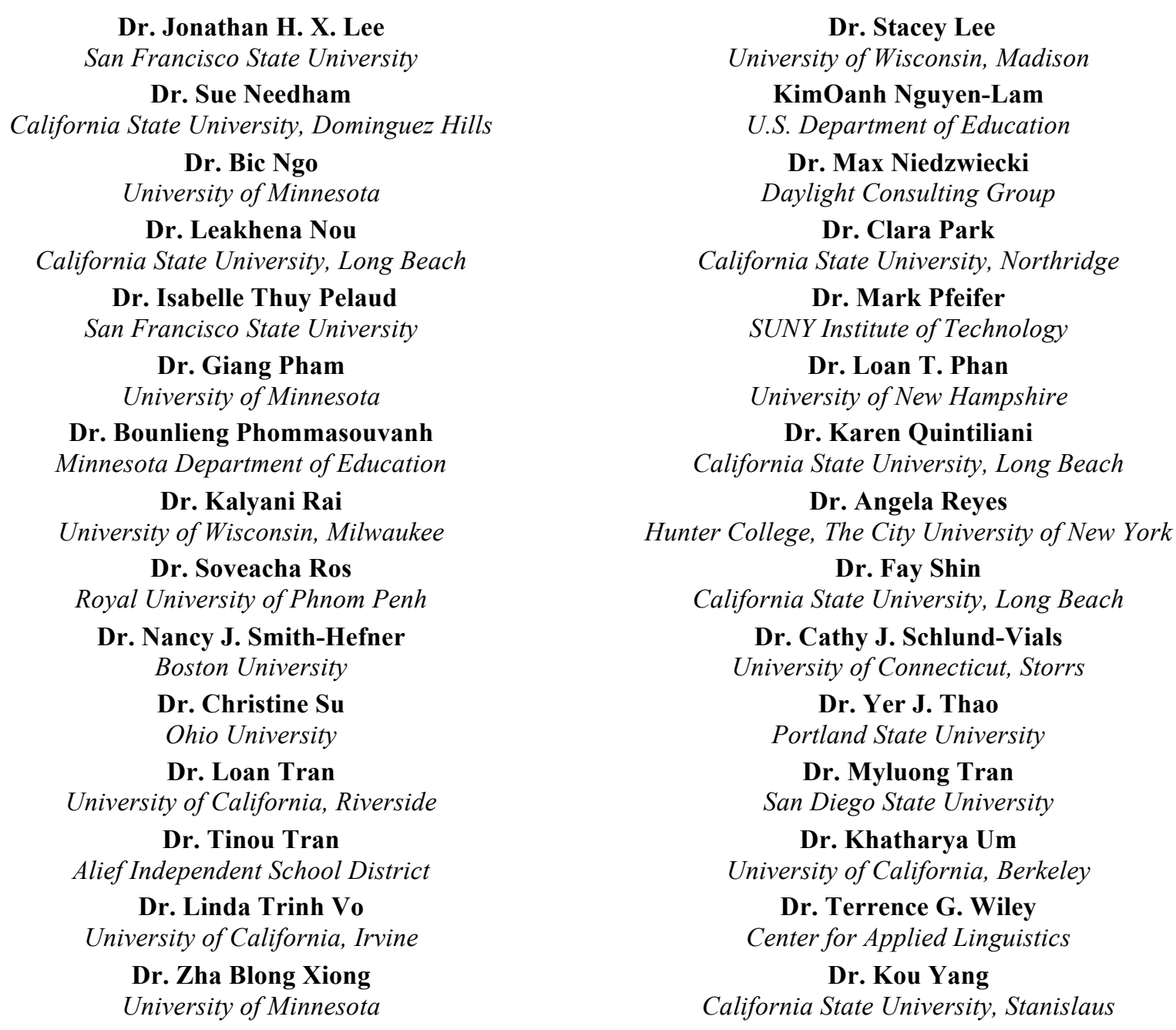

\section{Doctoral Student Editorial Review Board}

Virak Chan

University of Texas, San Antonio

Annie BichLoan Duong

San Joaquin County Office of Education

Peter Tan Keo

Columbia University

Monirith Ly

Texas State University-San Marcos

Hoa Nha Nguyen

University of Minnesota

Vanna Som

Harvard University

Krissyvan Truong

Claremount Graduate University

Yang Sao Xiong

University of California, Los Angeles
Keo Chea-Young

University of Pennsylvania

Ketmani Kouanchao

California State University, Fullerton

Ravy Lao

University of California, Santa Barbara

Thien-Huong Ninh

University of Southern California

Malaphone Phommasa

University of California, Santa Barbara

Alisia Tran

University of Minnesota

Silvy Un

University of Minnesota

Yeng Yang

University of Texas, San Antonio 